\title{
The Human Rights Field and Amnesty International
}

International actors, including the ICC, do not work in isolation. Others precede and contribute to their interventions and their rights-based representation of mass violence. Turning to those other contributors, located at the periphery of the legal field, this chapter focuses on civil society actors that advocate for human rights. How do they support a criminal law response to mass violence? How do they represent the events in Darfur? Specifically, what is their contribution to advancing a criminalizing frame for the interpretation of mass violence? I examine Amnesty International as a civil society case study. In my interview with her, the Darfur specialist in Amnesty's International Secretariat at the time of the most intense violence confirmed the centrality of the Darfur issue. She also spoke to her organization's focus on the rights perspective: "We are a human rights organization and we document, we try to document, human rights abuses, human rights violations. And we try to raise awareness, and we try to provide recommendations for all the actors who can have an influence to sort of change the situation."

This chapter begins with an overview of literature that attests to the growing role of INGOs in the prosecution and representation of mass atrocities. Then I present an in-depth discussion of Amnesty International, spelling out organizational goals and strategies and how goals are perceived by Amnesty staff and what representations of Darfur they generate. The analysis shows that the institutional logic of the legal field colors Amnesty actors' narratives about Darfur, the suffering of its 
people, responsible actors, and appropriate frames. An exclusive focus on features of the human rights field, however, would be misleading. The final section of this chapter shows how, even in an international and highly centralized organization such as Amnesty, national contexts of sections and workers interpenetrate with and at times weaken the logic of the legal field. Conclusions summarize insights gained in this chapter and anticipate chapter 3's discussion of the role of the United States.

\section{CIVIL SOCIETY'S HUMAN RIGHTS GROUPS AND THE ROLE OF AMNESTY INTERNATIONAL}

Generally, INGOs have been playing a growing role in the representation of mass violence to a global audience. Their number has grown substantially in recent decades (Khagram, Riker, and Sikkink 2002), and their presence is associated with greater respect for human rights within countries (Hafner-Burton and Tsutsui 2005; Tsutsui and Wotipka 2004). INGOs draft human rights documents, promote human rights, document abuses, conduct research, condemn or praise states and other actors, mobilize public opinion and public action, lobby governments, and provide humanitarian relief. Most specialize, for example, along the lines of human rights protection or humanitarian aid delivery. No matter their specialization, in all of their actions INGOs acknowledge and interpret violence. They frame it in various ways, in line with their central mission, and disseminate their representations of violence to a broader public.

INGOs and other international organizations are often part of larger, nonhierarchical networks called transnational advocacy networks. As explored in chapter I, TANs are bound together by shared values, a common discourse, and dense exchanges of information and services. Margaret Keck and Kathryn Sikkink (I998), who pioneered the study of TANs, focused on the power of ideas and norms, often called soft power, rather than more traditional forms of power. Information and the ability to frame violence are key to the power that activists, NGOs, social movements, and other members of TANs mobilize in order to draw attention to and increase support for their cause.

On the occasion of violent conflicts, INGOs are among the first actors to respond. My interviews with Africa correspondents from leading European and North American newspapers suggest that journalists often rely on NGOs as one crucial source of information. Journalists 
who reflect on their response to crises confirm that assessment (see the contributions in Thompson 2007). Such patterns of communication are to be expected given that major NGOs are represented in many parts of Africa, while even the most renowned newspapers typically have only one journalist on the ground, based in places such as Nairobi or Johannesburg, to cover the entire continent. Ways in which NGOs frame events may thus directly influence how violence is reported in news media across the globe, a topic to which I return in detail in chapter 9.

The importance of INGOs in the dissemination of knowledge is highlighted in the scholarly literature. World polity theorists, for example, argue that INGOs reflect the expression of world society and operate as carriers of global models and ideas (Schofer et al. 20I2). These scholars suggest that NGOs facilitate the global diffusion of a uniform narrative of events.

Critical theorists who write about INGOs agree with the reputed global character of NGO messages, but they strongly disagree with regard to their content. They insist, instead, that rights-based INGO narratives are colored by neocolonial interests. To them notions of human rights are Western in origin, reflect narratives of linear progress, and disguise interests of the Global North (Kennedy 2004). When NGOs frame human rights abuses and atrocities by using a metaphor of victims, savages, and saviors, Western countries and organizations appear as "saviors" (Mutua 2002). Their stories of human rights abuses suggest clear dichotomies between virtue and evil, while ignoring the nuances and complexities of social situations. In the case of Darfur, scholars such as Mahmood Mamdani (2009b) reproach Western media for conducting a "moralistic discourse whose effect is both to obscure the politics of the violence and position the reader as a virtuous, not just as a concerned, observer" (I49). Mamdani has in mind a wide variety of Western actors, from NGOs to writers such as Samantha Power, now US ambassador to the United Nations (see also Mamdani 2009a).

Constructivist traditions similarly embrace the importance of cultural models and norms. However, constructivists point out that NGOs are not just passive conduits of norms and ideas, as some world polity and critical research traditions assume, but rather actors with their own interests and desires to shape behavior (Keck and Sikkink I998), actors also who operate against the background of nation-states and their institutional environments, in which they originate and where they are headquartered (Stroup 20I2). NGOs do not just disseminate global narratives about conflicts; they create, modify, and interpret them, and 
they do so in line with their missions and foci. In the Darfur case, for example, humanitarian NGOs assess victimization and the role played by the Sudanese government more cautiously than rights-based NGOs, perhaps because they depend on the cooperation of the Sudanese government to deliver their aid (Hagan and Rymond-Richmond 2008).

\section{THE CASE OF AMNESTY INTERNATIONAL}

Amnesty International, together with organizations such as Human Rights Watch, the International Crisis Group, and the Enough Project, played a crucial role among INGOs in mobilizing world opinion and government action on behalf of Darfur. Amnesty's central role is not surprising in light of the organization's well-known history and current standing. Founded in I96I by British lawyer Peter Benenson, Amnesty today is the best-known and largest human rights NGO. London is the seat of its headquarters, the International Secretariat. Here the organization maintains its research office, whose primary mission was, early on, to identify and gather information on individual "prisoners of conscience" and to distribute such knowledge worldwide, a mission that has since been broadened (on Amnesty's history, see Neier 20I 2:I 86-203). Amnesty's success was partly based on its strict political impartiality. It took on cases under right- and left-wing abusers alike. It refused to accept government funds, instead relying solely on donations from small private donors and members. Highly qualified researchers, writing reports in its London office, strictly avoided sensationalism. The resulting moral authority contributed to a membership base of 160,000 in 107 countries by the mid-I970, a number that grew further to more than 500,000 in I 60 countries after Amnesty was awarded the Nobel Peace Prize in 1977. Over the years, Amnesty expanded its reach beyond representing the interests of individual political prisoners. One central mission became the mobilization of public opinion and enactment of government policies when massive violations of human rights occurred anywhere around the globe. Darfur became one of those cases.

In 2013 , for example, on the occasion of the tenth anniversary of the mass killings in Darfur, Amnesty International issued a report to update the public. The following short excerpt highlights the organization's concern both with the massive violation of the local population's human rights and with the impunity of leading political actors:

As the Darfur conflict marks its Ioth anniversary, the human rights situation in the region remains dire. Civilians continue to face attacks by government forces, pro-government militias, and armed opposition groups. In the last 
three months alone, 500 people were reportedly killed and roughly I 00,000 displaced in attacks against civilians that have involved members of government forces. The government in recent years has continued to carry out indiscriminate aerial bombardment and deliberate attacks against civilians. In addition, security services carry out torture and other ill-treatment against detainees and, alongside the police, use excessive force against peaceful protesters. And impunity reigns. Government officials, including President Bashir and a leader of the "janjaweed" pro-government militia Ali Kushayb, indicted by the International Criminal Court on counts of war crimes, crimes against humanity and genocide remain at large and there is little or no accountability for these crimes. ${ }^{\text {I }}$

The online publication cited here lists seventeen previous reports Amnesty issued over the past decade on the violence in Darfur. The first alert cited was issued during the second peak of mass killings ("Sudan: Darfur: 'Too Many People Killed for No Reason,"” February 3, 2004).2 An early example of intense field research, conducted by experienced research staff, appeared five months later under the title "Sudan: Darfur: Rape as a Weapon of War: Sexual Violence and Its Consequences." ${ }^{3}$ Following the typical division of labor, a researcher visited the field—specifically, the refugee camps in Chad-to interview affected women, and her colleague in London, in this case the campaigner for Sudan and East Africa, wrote the report. In the words of the latter, one of my interviewees at the International Secretariat: "[The rape study] was done by Annette [Weber], who went to Chad to do this. . . . I worked on the reports that came out of that." Reports and statements cited here illustrate well Amnesty's focus on the safeguarding of human rights. Means are not limited to criminal justice interventions, but they decidedly include them. Behaviors are referred to as crimes. Perpetrators, identified as targets of ICC prosecution, are named, including President Omar al-Bashir. Some of the evidence gathered in Amnesty reports is in fact suited for use by the prosecutor. Images displayed on Amnesty websites support the organization's messages (see figures 4 and 5).

Reports issued by Amnesty's International Secretariat in London are delivered to the national sections. There, country and theme specialists on Amnesty's staff use them to collaborate with volunteer groups on various campaigns in seeking to inform a broad public. They also pressure policy makers to take notice and to act on behalf of human rights. The following statement from an interviewee at Amnesty-Germany in Berlin describes how such work is executed:

I am here responsible for the coordination of our political work, that is, to pass on and present Amnesty demands and recommendations to the federal 


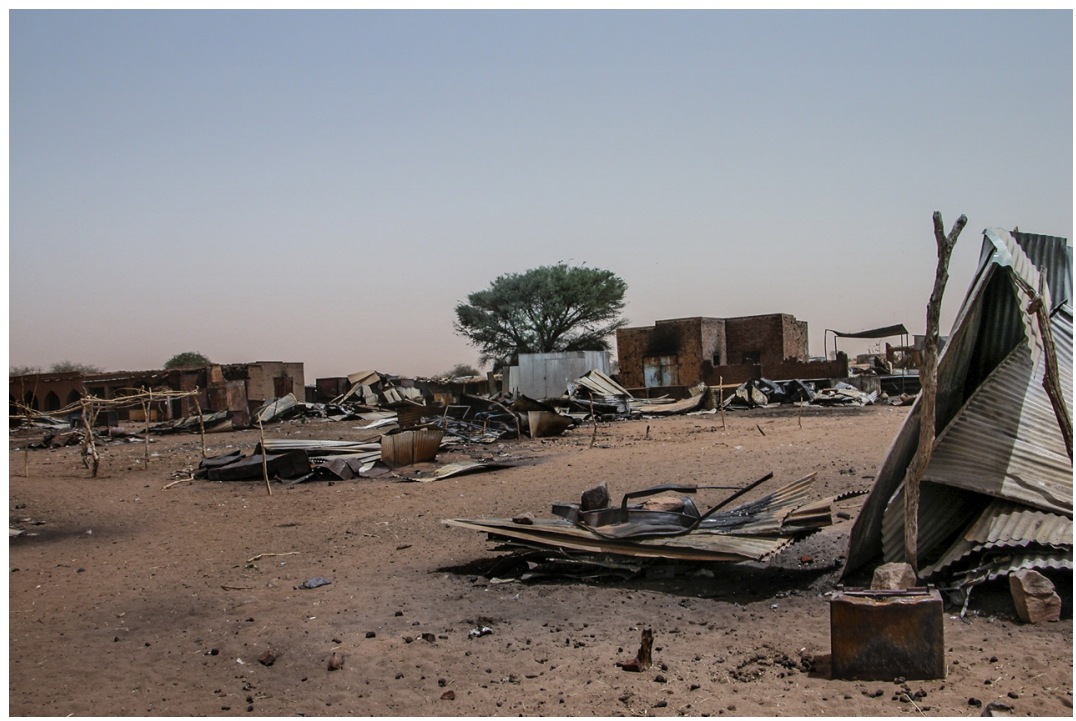

FIGURE 4. Darfur village attacked and burned by the Janjawiid. This image appeared on Amnesty International's website.

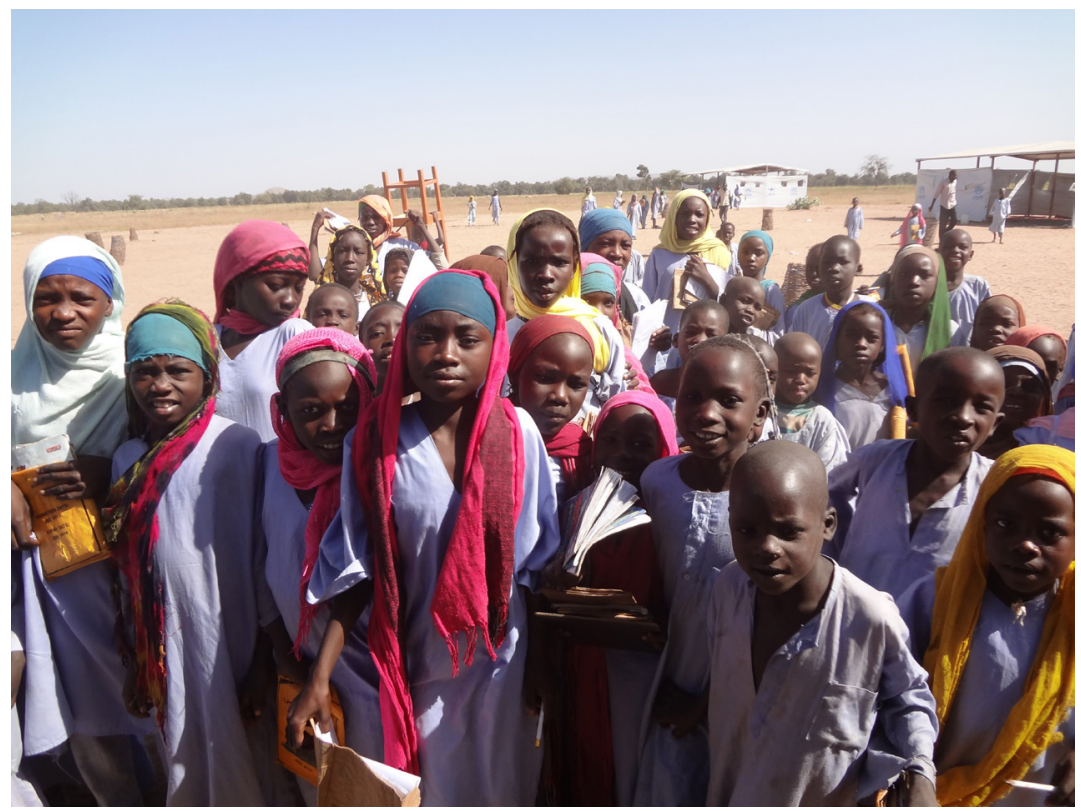

FIGURE 5. Darfuri refugee women and children in Chad. This image appeared on Amnesty International's website. 
administration and the legislature, and also to foreign embassies here in Berlin. A focus on which I really worked intensively is the impunity issue. That is not assigned to the country experts, but it's one of the themes that are coordinated by the secretariat general. These are the areas-impunity, work on the United Nations, the Human Rights Council, those issues thus-where country work coincides with institutional questions. And to decide, when we have a concern regarding Darfur, an arrest warrant against Bashir, for example, do we direct this to the legal department or the country section in the foreign ministry? What resources might have to get involved? Are we going to do this alone or in collaboration with other NGOs? ... I am responsible for these kinds of strategic questions. (author's translation)

The respondent, trained as a political scientist and responsible for political work at Amnesty-Germany, rushed from the interview we conducted in a fishbowl-like conference room to her office for a telephone conference with members of other NGOs. This conference's purpose was to prepare for a meeting with the Africa representative of the foreign ministry, a previous ambassador to Kenya and until recently head of his ministry's crisis staff. "The upcoming telephone conference," she told me,

serves the coordination among the participating NGO colleagues. When we are ten, to enter into a conversation with the other side and have one hour available to us, we then have to coordinate a bit. Who says what? Who pursues what foci? Where do organizations have common concerns that could be presented by just one participant? [Participating organizations at the upcoming conference included] Medica Mondiale, for which sexual violence against women is a central theme. That is also an important topic for Amnesty, but here we say that this is something that should rather be presented by Medica Mondiale, and where we say that we support their position. Then the humanitarian organizations will participate: World Vision, Oxfam, the Ecumenical Network Central Africa [Ökumenisches Netzwerk Zentralafrika], a very broad spectrum thus, also Human Rights Watch. (author's translation)

Amnesty International is a formal, centralized organization, and its guiding philosophy and crucial case-specific information, passed down from the International Secretariat in London, is taken seriously at the grass roots. One interviewee, a specialist for issues of arms and impunity for Amnesty-France in Paris, sheds light on (and supports) the highly formal and centralized nature of his organization. When asked about those he works with in his daily pursuits, he answered:

In general we depend strongly on Amnesty Londres [French for London]. . . . For example, Amnesty Londres said [to] us all the sections have to work on 
Sudan and Darfur and the arrest of Omar al-Bashir, because we have [a] strategic date in [a] couple of months to make pressure on [the] international community. So during six, seven months you have to concentrate ... and ... organize the pressure in France to push France in [the] UN Security Council to push Sudan to arrest Omar al-Bashir and render Omar al-Bashir to the ICC. . . . [I] in general I am waiting for the strategy of Amnesty Londres. And with the strategy of Amnesty Londres I organize the work in Amnesty France. And with my volunteer team I say, so you have to write to the ministry, plan meetings; you can organize an event with a movie, for example, to [sensitize] people; you have to write press releases to push France and have interviews with journalists. ... [W] have sixty or seventy sections in the world: Asia, Africa, Americas. ... In each country of the world Amnesty Londres has the capacity to mobilize volunteers to manage . . . a situation. If we have not this coordination, I think it will be very dangerous to work or inappropriate or inadequate. We will not be efficient. . . . And London has the capacity of research. In London you have all the researchers.

When asked about the most important source of information they rely on when seeking to understand a situation like that in Darfur, Amnesty staff and volunteers align closely with the above sentiments. All interviewees first refer to Amnesty's own reports. Most mention other sources only upon being prompted. Again the reply by the respondent of Amnesty-France may serve as an illustration. Asked what sources of information are most important to him when familiarizing himself with a case like Darfur and the indictment against al-Bashir, he answered:

Amnesty information. The [strength] of Amnesty International is the fact [that] we have our own research. . . . If I have information which is not checked by my researcher in London-I have a problem. . . . [S]ometimes when I have a doubt . . . I call or write London to have a discussion, to discuss the reliability, credibility of the information. ... We are unique in the world in this respect, because our research is reliable. It is serious. In terms of information, it is information from Amnesty thus that is most important to me. (partially translated by author)

Despite its centralization and the clear guiding definition of a human rights-based philosophy, Amnesty International is a living organization, composed of human actors of diverse nationalities, genders, and educational and occupational backgrounds who act in varied national environments. Thus, to learn about Amnesty's involvement in the case of Darfur and about ways in which it narrated the events, I turn in greater detail to a set of ten interviews. Seven interviewees were staffers; the other three, volunteers. Staff respondents were placed at different levels of the organization's hierarchy, ranging from the secretary-general of a national organization to theme or country specialists in national sections. 
Four had academic backgrounds in political science and international relations; four in law, including international human rights and criminal law; one volunteer had an engineering background (with the tenth's background unknown). Half had some additional educational degree, from anthropology to advertising. Most respondents had reached their current position via a variety of appointments. Yet none left any doubt about their identification with the pursuit of human rights as the organization's central mission. I conducted nine of the ten interviews in person, and one over the phone. Sites included the International Secretariat in London and national offices (staff) and homes (volunteers) in Paris, Washington, Berlin, Bielefeld, Vienna, and Bern.

\section{Goals as Perceived by Amnesty Actors}

Respondents at Amnesty International, like all other interviewees, were asked which goals should have primacy with regard to Sudan. I offered four options, but allowed for alternative suggestions: (I) seeking justice (by means of criminal law); (2) securing the survival of those affected by violence (through aid); (3) establishing peace (through negotiation); and (4) securing the sovereignty and integrity of the Sudanese state. The fourth option has obviously been a principle of international law since the Treaty of Westphalia of 1648 , which ended the Thirty Years War and which was negotiated with the hope that principles of nonintervention would secure international peace. Respondents spoke to all of these goals. Some merged the second (survival) and third (peace) to add a fifth: helping those affected through military peacekeeping missions.

Amnesty interviewees did not support all goals equally. In line with expectations, they most strongly backed the achievement of justice or, in other terms, the prevention of impunity. Every respondent subscribed to this goal. Three in fact identified justice as the only objective or declared that other goals (e.g., lasting peace) could be achieved only if justice was served. These three were lawyers, leaving only the fourth lawyer with a more varied portfolio of purposes. Four respondents wanted the pursuit of justice to be combined with the goal of helping the affected population survive. One of these declared that survival was one side-effect of the pursuit of justice. Seven pleaded for peace or peacekeeping as goals in addition to the pursuit of justice; one of these cautioned, however, that the establishment of peace must not occur at the expense of justice. One respondent expected that justice served would lead to peace. And only one saw a dilemma between the goals 
of achieving peace and justice simultaneously. Securing sovereignty, finally, was supported by only one respondent, a volunteer with an engineering background. In the Amnesty context, international rule on behalf of human rights clearly trumps national sovereignty.

One interviewee, responsible for political communication at her country's section office, spoke clearly to the primacy of the justice goal. When asked about potential conflicts between justice and aid delivery, she responded:

When we, in the case of Sudan, negotiate with the foreign ministry, jointly with colleagues from other NGOs, then that [the topic of cooperation with the government in Khartoum on humanitarian aid] will pop up. That, however, is not a point of contention within Amnesty, as we simply have a very clear position in favor of prosecution. Amnesty continues to be part of the grand coalition in favor of the ICC, and that can be summarized in the words "no peace without justice." There our position is very clear. Two years ago, on the occasion of the indictment against al-Bashir, we had a rather intense confrontation with Doctors Without Borders, for example, which took a very different position. We also had an exchange, not conducted in public, to communicate our positions to each other. Yes, this is an important point, but not a conflict within Amnesty. (author's translation)

Many interviewee statements could be added to illustrate this position, but I limit myself here to just one more, by an Amnesty-France interviewee. While the German respondent above draws a boundary between Amnesty's rights- versus humanitarian aid-inspired stances, this French respondent speaks to the distinction between a diplomatic position and that of Amnesty:

Justice is not negotiable. . . No one has ever proven that the arrest warrant against Omar al-Bashir impeded the peace process. For how many years has the peace process been going on!? For how many years has the government of France organized the conference in Doha, with the different rebel groups, with the government of North Sudan!? For how many years has one discussed!? For how many years!? . . . And the arrest warrant has never kept these negotiations from proceeding, never. That is thus a false problem [faux probleme]. And how can one have peace, how reconstruct a country with the victims, if there was no reparation, no truth? That is not possible, not possible. The case of South Africa is emblematic. They had a Truth and Reconciliation Commission. Now, one can critique that commission, one can critique their work and how they went about it, but all Africans recognized that that commission played a central role in the reconciliation between black and white at the end of Apartheid. . . . Today, how do you want to construct peace at the expense of justice and have trust in those who have massacred their population? . . . It is thus that we never juxtapose justice and peace. For us they are intimately related. And one knows that justice 
has a deterrent effect. Milošević participated in the Dayton Accords-and that was followed by a process which contributed to his arrest because there was an international tribunal. And the Bosniac forces contributed to his arrest and extradition to the tribunal because the tribunal also had the capacity to dissuade those who had endured the violence from taking violent revenge, but rather to favor the arrest of that person. Justice has a deterrent effect, extremely strong. (author's translation)

Elsewhere in the interview, the same respondent stressed that Amnesty staff are not uninterested in sociological and political conditions of conflict, but that these concerns are subordinate to the rationales of the justice perspective:

One denounces, and one does not cease to denounce, for example, the death penalty. But one does not tell the Chinese-or China—"adopt a US type regime, for example, adopt a Chinese democracy." No. One simply denounces all they inflict upon their population. Here you go. And I believe that this is one of the strengths of Amnesty, to have that distance to the international political system or to political situations at the national level, such as in Sudan, in order to report nothing but the voice of the victims. . . A right constitutes obligations. Obligations, responsibilities, pursuit of justice. ... . [Asked if sociological or political causes are thus irrelevant to Amnesty, he adds in English:] Yes. But we are not stupid and we need to understand personally the situation. So maybe we go to a conference to meet specialists on the question, to have a view, a general view of the situation and understand ethnic problems, energy problems, political problems. But it is to facilitate our work; it is not a condition of our work. (partially translated by author)

In short, these statements illustrate that not just official proclamations and declarations by the International Secretariat in London, but also goal setting as articulated by my interviewees from Amnesty from a diverse group of countries, place the organization unmistakably in the justice field, albeit at its periphery. Respondents' identification with Amnesty's institutional logic is especially pronounced where organizational membership coincides with legal training.

Interviews do not reveal if this identification of justice, or the avoidance of impunity, as a goal results from selective recruitment or socialization into the organization's culture. Socialization through organization and communication does seem crucial, though, as indicated by participants' almost unanimous orientation toward the International Secretariat as the best source of information. Be that as it may, membership in Amnesty, for volunteers, but especially for staff, appears to color the habitus of its members, as well as their identification with an institutional logic that corresponds with the pursuit of justice by means of criminal law. 


\section{Representations of Darfur by Amnesty Activists}

How does this identification with the organizational goal of human rights and justice translate into Amnesty workers' representation of the Darfur conflict? How similar is their narrative to those encountered in legal documents (chapter I) or to the account of criminologists such as John Hagan and Wenona Rymond-Richmond (introduction)? The narrative or representation of the Darfur conflict, as presented by Amnesty interviewees can best be explored along the dimensions of suffering and victimhood; origins of the conflict, time dimension, and causes; identity of actor-perpetrators; and frames applied. Seven out of ten Amnesty interviewees, representing the International Secretariat in London and five individual countries (United States, France, Germany, Austria, and Switzerland), provided substantive answers to most of the themes covered here.

In response to questions about suffering and victimhood, seven interviewees spoke about victimhood and the suffering of the Darfur population; one additional respondent (Ireland) referred me to related accounts in an Amnesty report. Specifically, six interviewees spoke about killings and death, and one about executions and disappearances. Six addressed rape (including "mass rapes" and "mass rape as an instrument of ethnic cleansing"), and six referred to displacements (including those termed "irreversible"). Torture, looting, destruction, and violations of human rights are also mentioned. Obviously, suffering and victimhood are foremost in the minds of Amnesty interviewees, and they are primarily described in the language of criminal law.

When asked about causes and origins, Amnesty interviewees, while also speaking to long-standing conflicts in the region of Darfur, especially old conflicts between ethnic groups and between pastoralists and farmers, focused on present-day conditions. A major concern was with government policies that "discriminate" and "marginalize." Respondents thereby attributed responsibility to the government of Sudan for creating background conditions that foster conflict. But they went further by also identifying government action as a direct cause of the violence. They spoke to the "politicization of old conflicts" or the "instrumentalization" of tensions in the region by the al-Bashir government and to the government supplying "Arabs" with weapons. Such a focus on the present is in line with the criminological representation of the Darfur conflict by Hagan and Rymond-Richmond. It approximates judicial narratives. 
Interviewees were more specific yet. Seven of them named actors whom they deemed responsible for the suffering of the people of Darfur. All but one mentioned the government of Sudan; five referred explicitly to al-Bashir, the "Bashir regime," or government actors "up to the Presidential level." Four mentioned the Janjawiid or "Arabs, supplied with weapons"; and (only) two see "rebels" or "opposition groups" as responsible for the violence.

One interviewee came closest to representing the violence in Darfur in almost ideal-typical terms of criminal law and justice. This is not surprising, as here we encounter a young lawyer, the head of AmnestyGermany's volunteer group on issues of impunity, a former intern at the ICC's prosecutor's office who had also spent time with the tribunal in East Timor and who was earning her living as a prosecutor in Berlin. She spoke about causes, suffering, and perpetration of crimes in Darfur in these terms:

I would say it is a conflict that originates in ethnic tensions and that has been instrumentalized by the central government in Khartoum, to document its territorial claims in Darfur. The causes of the conflict lie in the differences between the ethnic groups in Sudan, but also in their ways of life and in a will of those groups living in Darfur to continue to conduct their self-determined lives and to distance themselves from the central government, an attempt that the central government does not necessarily support. The execution of the conflict is yet another question. . . . The government sent out [horse/ camel-]riding groups, collaborated with the Janjawiid militias thus, which it instrumentalized, and that helped their country's army, to show their dominance, as it were. In the course of this, hundreds of thousands have been driven from their homes and killed. Rapes were a strong characteristic of this conflict, and it is one of the cruelest conflicts of the past years. ... And it was planned and purposefully conducted. Different from descriptions by many, it was not simply a clash between ethnic groups that conducted a civil war. That, I would say, it was exactly not. But what precisely occurred, and how it is to be evaluated judicially, there we have to wait for word from the ICC-when one day proceedings will finally be under way. (author's translation)

Not only is this narrative in line with the logic of criminal law and justice, explicating the actus reus, naming offenders, and declaring their intent, but it is also partially subservient to the juridical proceedings. The final story can be told, in the mind of this respondent, only once the court has done its work. I found the same deference, the same hesitancy to label the crimes without the court having spoken, in a number of interviews with lawyers, not just at Amnesty. 
Finally, inquiring about the appropriate frame through which the Darfur conflict should be interpreted, I again offered interviewees four options: a rebellion or insurrection frame (understanding government action as counterinsurgency); a civil war frame; a humanitarian emergency frame; and a state crime frame. In their responses, only one respondent supported the insurgency frame (engineer-volunteer), one rejected it explicitly (general secretary, lawyer), and three subscribed to it either with hesitation or by stressing that the insurgency by rebel groups was a response to government action. Only one respondent accepted the civil war frame, three rejected it explicitly, and one accepted it only under the condition that civil war in Darfur be seen as a consequence of previous criminal state action. Almost all respondents accepted the label of humanitarian catastrophe, though one of these insisted that it should be considered as such only if one recognizes that the crisis resulted from criminal aggression by the state. One respondent hesitated using the label humanitarian catastrophe as, in his opinion, it omitted the situation's human-made character (general secretary, lawyer). Yet, in line with the narrative described here along four analytic dimensions, all of the respondents but one wholeheartedly embraced the state crime frame.

In short, interviewees among Amnesty's staff and volunteers were largely in line with the guidance provided by the International Secretariat in London. They were determined that the pursuit of human rights is of the utmost importance, that criminal law and justice should play the central role in response to mass violence, and that impunity must be avoided by all means. Some also insisted that pursuing justice will eventually serve other goals such as the survival of those affected and the establishment of peace. Potential goal conflicts were thus neutralized.

Despite such unanimity, I observed patterns of distinction even within our small sample of interviewees. The lawyer-versus-political scientist distinction appears to carry particular weight, with lawyers defining goals and presenting narratives in ways even more clearly in line with the ideal type of criminal law and justice than those of other Amnesty members, staff, or volunteers. This pattern resembles those identified elsewhere in political administration (Stryker I989) and within the ICC (Meierhenrich 20I4). But I have to pour more water into the wine of a pure criminal justice perspective. Another pattern I observed demands that we modify the notion of a universal and globalized representation of mass violence by an international rights-oriented organization. I refer to national distinctions, to which I turn now. 
NATIONAL CONTEXTS OF NGO WORK AND THE CASE OF AMNESTY

International NGOs are, by definition, border-crossing organizations. Their emergence and influence is in line with theoretical arguments from the world polity, neoinstitutional, and constructivist schools. Yet a specific branch of neo-Weberian work in comparative sociology and recent insights particularly regarding INGOs have stressed the considerable weight of national context in the definition of situations. Most INGOs continue to be headquartered in the countries where they were founded, and they continue to receive a substantial portion of their funding from within these "home" countries. Developing this point through an empirical examination, Sarah Stroup (20I2:3) argues convincingly: "While many NGOs are increasingly active in international arenas, I find that actual organizational structures and strategies are deeply tied to national environments." Her detailed analyses confirm that this pattern applies especially for humanitarian, but also for human rights INGOs. Stroup focuses on regulatory frameworks, political opportunity structures, availability of resources, and social networks as features to which INGOs are exposed and that vary by country. She shows how such contextual conditions color INGOs' professionalization and management, fund-raising, advocacy and research, and issue selection. My point here is that they also color the representation of human rights violations.

The rights-based INGOs that Stroup examines include United Kingdom-based Amnesty International and, by contrast, Human Rights Watch, based in the United States, along with the Fédération Internationale des Ligues des Droits de l'Homme (FIDH), based in France. Compared to the latter two, and owing to donation patterns in the United Kingdom, Amnesty depends more on fund-raising from multiple individual donors. Levels of professionalization also differ. HRW, for example, depends on a high level of professionalization, a functional necessity because of its dependence on large foundation donors. Consequently, HRW also relies more on insider strategies (e.g., links to the US government), compared to a preference for grassroots mobilization within Amnesty and, even stronger, in FIDH. In terms of issue selection, both HRW and Amnesty have been much more reluctant to address social, economic, and cultural rights issues than the French FIDH. Stroup attributes this caution to the American and British constituencies' greater attunement to free market and individual rights principles than their French counterparts exhibit. 
But Stroup goes further. Beyond identifying differences across distinct human rights organizations, she also explores distinctions of national sections within INGOs. For Amnesty, for example, despite its high degree of centralization and the concentration of more than a quarter of its \$200 million budget in the International Secretariat in London, she finds significant national particularities. Among the eighty national sections, Amnesty-USA depends more than the others on large financial donations of less involved supporters, a funding pattern similar (albeit not as pronounced) to that of HRW. National donation practices thus matter at the level of sections, as well. Further, while research at Amnesty is "in some ways a valuable end in itself," the US section sets somewhat different priorities. As one staffer indicated, "We in the US think in terms of timeliness and impact, but they [the International Secretariat] think in a way that is unhurried, more thorough, and these are cultural differences. . . . To me, it sometimes feels like a group of people in universities in London, developing long, detailed documents" (cited in Stroup 201 2:160).

Country-specific opportunity structures that affect organizations and sections within organizations spelled out by Stroup are supplemented by others, including nation-specific carrier groups, historical experiences, and the distinct cultural sensitivities these evoke. Collective memories and cultural trauma-for example, those pertaining to war and mass violence-and associated national identities take country-specific shape (Savelsberg and King $2005,20 \mathrm{II}$ ). In addition, civil society is more easily mobilized in some countries such as the United States, with its strong tradition of associational life and prominence of single-issue groups, but slower to move to action in others with more neocorporatist arrangements (Kalberg 20I4). Also the organization of news media varies. Market-driven media, as compared to publically funded ones, are more receptive to societal sentiments and prone to sensationalist reporting (Benson 20I3), for which the United States provides a good example. In addition, government institutions are more or less open to civil society input. And here too the boundary between civil society and the state is more porous in the United States than in other Western democracies, as a long line of sociological work has shown (Bendix [1949] I974; Roth 1987; Rueschemeyer 1973; Kalberg I994, 2014; Savelsberg and King 2005).

Interviewees at Amnesty were clearly sensitive to the state- and society-based contexts within which their sections have to operate, despite their frequent deference to the International Secretariat. They 
know, for example, that their governments are more receptive if the issue at hand concerns a former colony, especially if the country hosts refugees and expatriate organizations from those former colonies. In the words of a respondent at the International Secretariat in London, an energetic person of French descent (from an overseas French province) who had earned a degree in political science and international relations at Science Po in Paris and in anthropology at the renowned School of Oriental and African Studies (SOAS) at the University of London:

I think-obviously, because we are based here-you know, we do have more regular access to UK diplomats, but I think I am also maybe more aware of the role that the UK plays on Sudan, on Darfur, because they played a very important role in the North-South peace process, [because] they are the former colonial power, and because of their seat at the Security Council.... [Y]ou will hear a lot more talking about Sudan and former British colonies in the UK. And if you are in France you will hear a lot more about Algeria, Morocco, Tunisia, etc., etc. . . I think it is often because there is a lot of Sudanese refugees in the UK, there is a lot of refugees and migrants from North Africa in France. ... [W] have to try to take advantage of all this attention to try to push for our human rights agenda.

Two French Amnesty interviewees strongly confirmed the weight that status as a former colony has for their national government, and they drew conclusions for their strategizing. In the words of one:

The French section works a lot on African countries, and the old colonies of France-because we know that France has the capacity again to influence these countries, because of the history of France and Africa and these countries. So, yes, we have a particular focus on francophone African countries. ... [I]n Amnesty-France we have two researchers, who are based on the second floor, and they are specialists on western Africa.

Another country-specific feature Amnesty workers have to be mindful of if they hope to communicate effectively with their governments, is the history and status of the country's neutrality. Asked whether Switzerland's position vis-à-vis the Darfur conflict differs from that of other countries, an Amnesty staffer in Bern argued: "I think it barely does with regard to the evaluation of the Darfur conflict. In terms of practice, I'd say "yes," first because Switzerland almost never, as a matter of principle, participates in UN peacekeeping missions. [JJS: No humanitarian interventions?] No, or if ever, just as an alibi, two, three officers or such" (author's translation).

In addition to being sensitive to their government's position when they launch campaigns, Amnesty respondents appear to be especially 
attuned to their constituents' sensitivities and motivational forces. A sense of historical obligation, for example, resulting from their country's execution of the Holocaust, resonated from my interviews with German Amnesty staffers and volunteers alike. One volunteer, head of AmnestyGermany's impunity group, illustrated this historically grounded sense of commitment well. She simultaneously indicated, though, that such commitment may be associated more with a leaning toward humanitarian than toward penal responses to mass atrocities:

The churches are very much engaged in this respect, partially out of humanitarian concerns, but also with a view toward our own past, and the churches do have substantial influence in Germany-still. This group I would name. And they just have strong roots in the bourgeois [bürgerliche] middle classes. ... It's more motivated by humanitarianism in Germany. Many people are engaged in humanitarian charities. I would always look at things from a criminal law perspective, but only few do so. Most see this as a humanitarian catastrophe with immense consequences. (author's translation)

This statement suggests that carrier groups and the strong position of churches in Germany's neocorporatist makeup influence the reception of the Darfur issue in that country. Another factor appears to be the institutionalization of the theme of genocide in German school curricula. The same interviewee spoke to the resulting responsiveness of the public to genocide issues by drawing on her own experiences:

I think many Germans easily understand, as genocide and our history are being taught in school. One is able to draw parallels quickly when one begins to engage with the conflict. I certainly experienced that with Rwanda. I was still young back then, but both Rwanda and Yugoslavia were prominently reported in the news media.... That was I994 and I was fifteen years old, in tenth grade, so this was a topic [in school], also at home, and these two conflicts had a strong influence on me. (author's translation)

Again, historical experiences and their processing into collective memory create public sensitivities that sections of INGOs such as Amnesty have to take seriously in order to act effectively toward their domestic constituents. The foregoing interview segment illustrates further that it matters which organizations and carriers dominate in the processing of history and in its application to current situations of mass violence. Needless to say, the respondent's perception is not based on social science analysis. But what matters here is the perception of an Amnesty member and its potential to color her organization's representation of the Darfur conflict. 
Related historical legacies create additional country-specific sensitivities that INGOs have to take seriously if they want to function effectively in a given country. These include devastating experiences with aggressive militarism and their subsequent processing. Interviews with Amnesty staff in both Germany and Austria indicated that such experiences have generated pacifist leanings, especially within those population segments attracted to joining human rights organizations. And such leanings affect the discursive range available to their respective sections. A German Amnesty volunteer, head of the Sudan group, spoke to this point: "In 2006 we had the big issue here at Amnesty when the UN was supposed to receive a stronger mandate. ... Then we had a major debate, especially here in Germany, because we have many Amnesty members from the peace movement, who rejected that, when the word intervention was articulated and intervention is always associated with the use of military force in the back of one's mind" (author's translation).

Another domestic force made itself known in my interviews, particularly in my conversation with the secretary-general of Amnesty-Austria: the entanglement of a country's industry in mass violence abroad, and the response that the discovery of such involvement evokes. In the Austrian case it became a motivating factor, in the absence of which the section, small and thus selective by necessity, may not have addressed the Darfur conflict. The story began with an American journalist who found a brand-new Glock pistol, made by the renowned Austrian firearms producer, in the hands of a Darfur rebel. The journalist noted the weapon's serial number, and when Amnesty was informed, it began to question Glock and the Austrian government, "How can that get there?" the secretary-general recounted.

Darfur is a weapons embargo zone, for both the UN and the EU. There are of course millions of old weapons, hundreds of thousands of old weapons, but a recognizably brand new Glock pistol, for which you can still trace how the embargo was broken ... That was a very tricky question, initially, and weapons' trade is maddeningly difficult, it's a very untransparent realm, where there is little transparency on the side of states: . . "Dear Glock company, dear state of Austria, please explain to us how that got there. To whom did you sell this first, how did it move on from there, has it been stolen, sold on the back market?" (author's translation)

Glock responded, irrationally in the judgment of my interviewee, by suing Amnesty as an organization and its secretary-general personally. The criminal court process for defamation before the district court (Landgericht) was accompanied by a suit in trade court (Handelsgericht) 
for damages amounting to 200,000-300,000 Euros. The trials, which the company eventually lost, lasted three years and attracted much publicity. "And Glock tried all the time to insist that that is not possible," the secretary-general continued,

because this pistol was exported to Kuwait and surely did not move on from there. Because they put so much pressure on us, we invested a lot of investigatory energy and were thus able to prove that there is a hunting weapons, that is, a hunting safari, business in Kuwait, with a branch in Sudan, because Sudan is such an attractive hunting ground, and that safari participants were equipped with weapons, and that weapons can also be smuggled along this path. Having been put under such pressure, we thus invested much energy to trace the path and identified one of the, of course, thousands of weapons trade and smuggling routes, where Glock certainly was not the smuggler, but knew full well why that little weapons trader in Kuwait was so interested in such large amounts. There was thus a purely accidental but intensive interest ... in the human rights situation in Darfur... Research, legal background, ... also public issue raising, always more under the angle of weapons trade, but also to explain, of course, why this embargo is so important, because the human rights situation in Darfur is so catastrophic. (author's translation)

In short, national sections of INGOs have to be mindful, first, of their domestic government's priorities if they seek to affect government policies and, second, of public sentiments if they hope to mobilize followers and secure donations. While strongly oriented toward the International Secretariat, staff and volunteers at Amnesty's national sections were mindful of specific domestic opportunities and constraints: the government's power position in the international community (e.g., representation on the UNSC); colonial history and the representation of expatriate communities (e.g., the United Kingdom and Sudan); the section's size (number and selectivity of issues addressed); links between local forces, such as industries, and actors in the conflict zone (e.g., the Austrian Glock story); collective memories and a resulting sense of obligation (e.g., memories of the Holocaust and militarism in Germany and Austria); and dominant carrier groups (e.g., churches and humanitarian aid organizations in Germany). Amnesty-USA faces yet a different set of conditions, to which I turn shortly.

\section{CONCLUSIONS}

The core of the justice field, especially the ICC, does not fend for itself in the pursuit of criminal justice. Establishing a criminalizing frame 
through which to interpret the mass violence in Darfur is propelled by a variety of global and national forces in support of the justice cascade (Sikkink 20II). Prominent among global actors are INGOs (Keck and Sikkink 1998). My in-depth analysis of Amnesty International concerning the case of Darfur illustrates this organization's fight to end impunity. Its narrative resembles that of actors in the criminal law and justice field. While Amnesty members also highlight goals such as the establishment of peace and the survival of victims, interviews show how activists rationalize away potential conflicts between the latter goals and the pursuit of justice. They insist that justice, once achieved, will help reach other goals, or even that other goals cannot be reached if justice is not served. Such relative unanimity among my interviewees, despite distinct national backgrounds, supports the recent scholarly focus on globalizing forces in the formation of norms and scripts and their potential effect on local and national practices, for example in research by the World Polity School (e.g., Meyer, Ramirez, and Soysal I992; Frank, Hironaka, and Schofer 2000; Schofer and Fourcade-Gourinchas 2002).

Yet caution is warranted. Unanimity is only relative. The case of Amnesty shows that-despite its hierarchical organization-conditions within which national sections operate also matter. This finding is in line with recent literature about national contexts of INGO work (Stroup 20I2), as well as a long tradition of neo-Weberian scholarship that focuses on nation-specific carrier groups and institutional arrangements (Bendix [1949] 1974; Gorski 2003; Roth I987; Rueschemeyer I973; Kalberg 1994, 2014; Savelsberg and King 2005). It is, finally, congruent with recent scholarship that shows how the spread of global norms is filtered through cultural specifics at the local level and through a country's power position within the international community (Boyle 2002; Halliday and Carruthers 2010). Interviews make clear that Amnesty workers within national sections are aware of their government's traditions, interests, and policy foci when they seek to influence government policies. They are also mindful of nation-specific cultural sensitivities and business interests (as in the Austrian Glock case) when they mobilize volunteers and the public and raise funds. Such mindfulness in fact is a precondition for effective work at the local and national levels, even among international NGOs.

My interview with an American Amnesty activist about her organization's functioning in the context of the Save Darfur campaign especially illustrates how Amnesty volunteers, despite the organization's centralized organization, adapt to national environments through 
organizational and linguistic strategies. This adaptability may be considered a strength or a weakness. In the case of Amnesty it certainly did not weaken the INGO's unifying message as represented in official outlets such as Amnesty-USA websites. These observations should in any case direct our attention to ways in which national sections of INGOs are embedded in and interact with other civil society and government actors in specific national contexts. The United States provides an excellent example in the context of the justice field, as it eventually became a strong supporter of a rights-oriented criminal justice response to the violence in Darfur, despite its objections to the ICC. How did this seeming paradox become possible? The following chapter seeks to provide an answer. 